

\title{
Nordisk råd - vårt råd
}

(C) Nordisk råd, 2012

ISBN 978-92-893-2375-8

http://dx.doi.org/10.6027/ANP2012-734

ANP 2012:734

Redaksjon: Silje Bergum Kinsten/Heidi Orava

Layout: Jette Koefoed

Fotografier: Karin Beate Nøsterud; Ingram; Image Select; Ojo;

Søren Sigfusson; Ludwig Ehlers/Landesarchiv Berlin;

fotografier fra «50 år Nordisk Råd 1952-2002»

Opplag: 3500

Trykk: Rosendahls-Schultz Grafisk, Albertslund

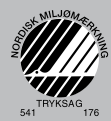

Printed in Denmark

\section{Det nordiske samarbeidet}

Det nordiske samarbeid er en av verdens mest omfattende regionale samarbeidsformer. Samarbeidet omfatter Danmark, Finland, Island, Norge og Sverige samt Færøyene, Grønland og Åland.

Det nordiske samarbeid er både politisk, økonomisk og kulturelt forankret, og er en viktig medspiller i det europeiske og internasjonale samarbeidet. Det nordiske fellesskap arbeider for et sterkt Norden i et sterkt Europa.

Det nordiske samarbeid ønsker å styrke nordiske og regionale interesser og verdier i en global omverden. Felles verdier landene imellom er med til å styrke Nordens posisjon som en av verdens mest innovative og konkurransekraftige regioner.

\author{
Nordisk råd \\ Ved Stranden 18 \\ DK-1061 København K \\ Telefon (+45) 33960400
}

www.norden.org

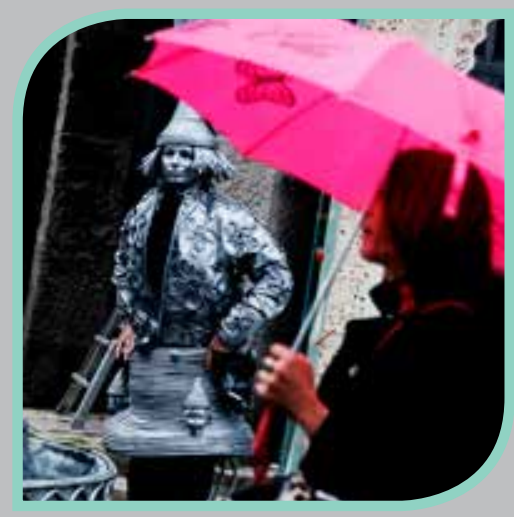




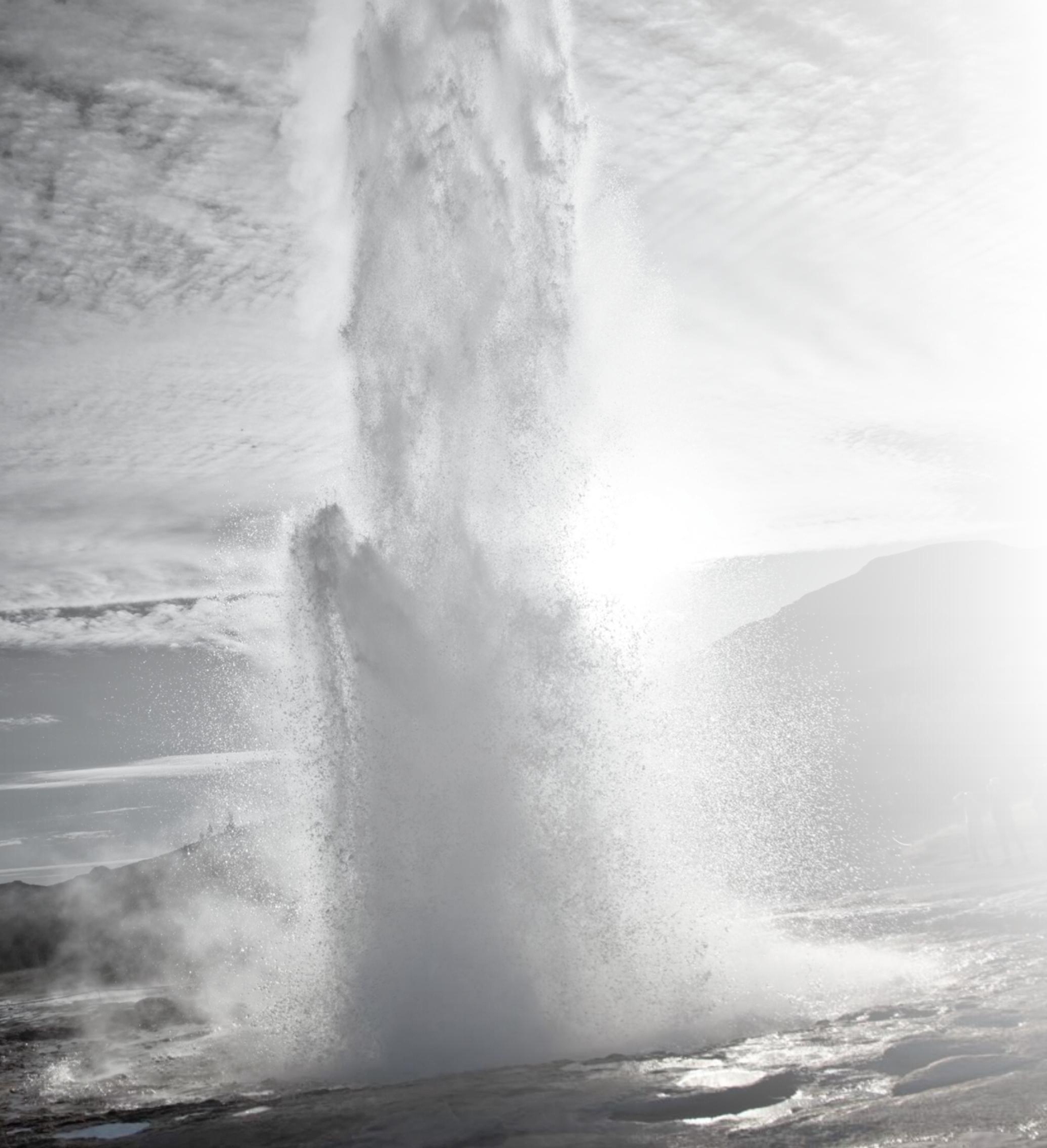


I denne brosjyren får du

vite mer om hva Nordisk råd dreier seg om. Du vil oppdage at Nordisk råds arbeid også påvirker ditt liv. Kanskje vil du også være med på å påvirke Nordisk råd.

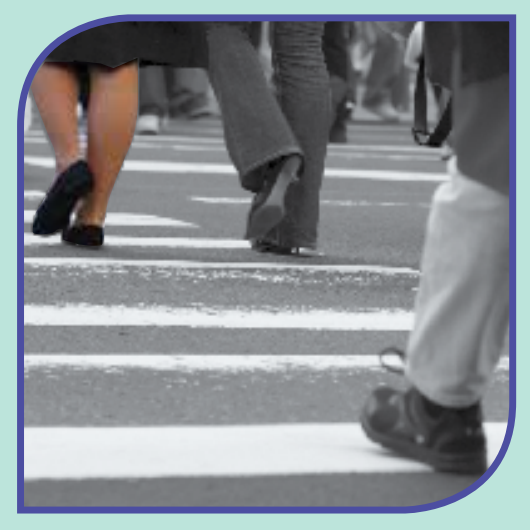




\section{Nordisk råd \\ - vårt råd}

Innledning

Etter katastrofen

De første skrittene

Tidslinje

Hvilke spørsmål arbeider Nordisk råd med?

Nærmere folket

Fakta om Nordisk råd 


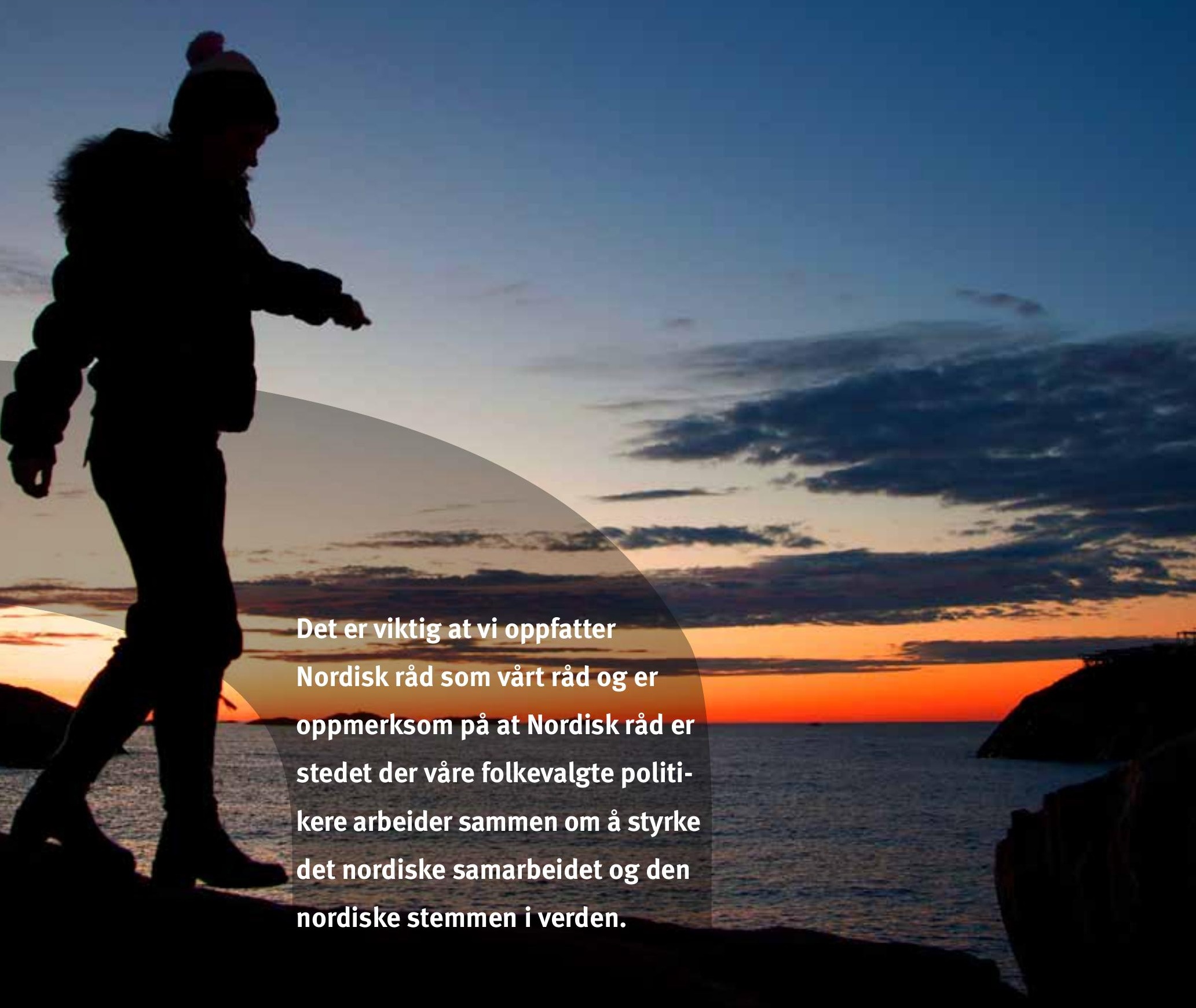




\section{Innledning}

Nordisk råd har eksistert i over seks tiår. På mange måter har alt forandret seg - tenk på levekårene våre nå i det 21. århundre i forhold til 1952, tenk på hva teknologien er i stand til i dag, og på hvor mye vi beveger oss på kryss og tvers av grenser ikke bare i Norden, men i hele verden.

De nordiske landenes sterke kulturelle, sosiale og demokratiske verdier har vært viktige i hele Nordisk råds levetid. Det er naturligvis også disse felles verdiene som skal bære Nordisk råd videre inn i framtiden. Men vesentligst er imidlertid at vi i Norden fortsatt vil oppfatte rådet som relevant for oss helt alminnelige nordboere. Det er viktig at vi oppfatter Nordisk råd som vårt råd og er oppmerksom på at Nordisk råd er stedet der våre folkevalgte politikere arbeider sammen om å styrke det nordiske samarbeidet og den nordiske stemmen i verden.

Veien til å oppleve at Nordisk råd er vårt eget råd, går gjennom forståelse. Og den kommer fra kunnskap. Om Nordisk råds historie, om Nordisk råds sammensetning og ikke minst om hva Nordisk råd arbeider for hver eneste dag i alle de nordiske landene, men også ute i verden. For Nordisk råd vil og kan gjøre en forskjell for befolkningene i Norden, og forhåpentlig også for andre land og befolkningene der.

I denne brosjyren får du vite mer om hva Nordisk råd dreier seg om. Du vil oppdage at Nordisk råds arbeid også påvirker ditt liv. Kanskje vil du også være med på å påvirke Nordisk råd.

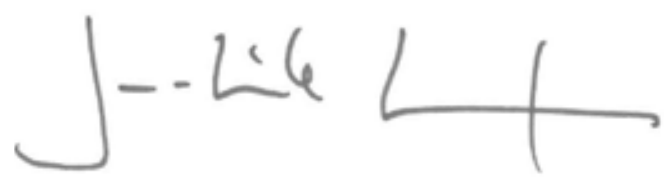

Jan-Erik Enestam

Direktør

Nordisk råd 


\section{Etter katastrofen ...}

Historien om Nordisk råd begynner da andre verdenskrig slutter. Europa var ødelagt fra nord til sør og fra øst til vest. Sivile var på flukt, utryddelsesleirer ble funnet, det kom stadig fram nye historier om de utroligste menneskelige tragedier - og i Japan hadde USA sluppet to atombomber med ufattelig ødeleggende konsekvenser. Den gamle verden var knust. Men heldigvis kom gjenoppbyggingen raskt $\mathrm{i}$ gang, og et viktig nytt politisk forum som FN oppsto i 1945 for å skape et rom for internasjonal dialog og samarbeid.

I Norden sto vi med en felles fornemmelse av at vår beskjedne størrelse kunne bli et problem i en usikker verden. Man trengte bare å se på store naboer som et sønderbombet Tyskland og et uberegnelig Sovjetunionen. Hva ville kunne skje der?

Følelsen av ubalanse og usikkerhet var altså massivt til stede på slutten av 1940-tallet, og de nordiske landene kunne se at de mange språklige og kulturelle fellestrekkene kunne utnyttes bedre. Samfunnssystemene våre var ikke identiske, men likhetspunktene var flere enn forskjellene. Ideen om et nordisk samarbeid oppsto derfor ut fra et ønske om å gi Norden en større og sterkere stemme i en tid da ingen kunne forutse den politiske utviklingen. Den folkelige støtten til opprettelsen av Nordisk råd var stor, og Foreningen Norden var en sentral og drivende kraft for denne folkebevegelsen.

\section{Følelsen av ubalanse og}

\section{usikkerhet var altså massivt til}

stede på slutten av 1940-tallet,

og de nordiske landene kunne

se at de mange språklige og

\section{kulturelle fellestrekkene kunne} utnyttes bedre.

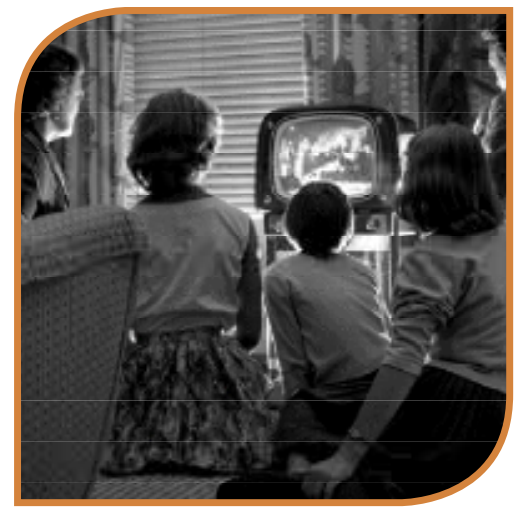




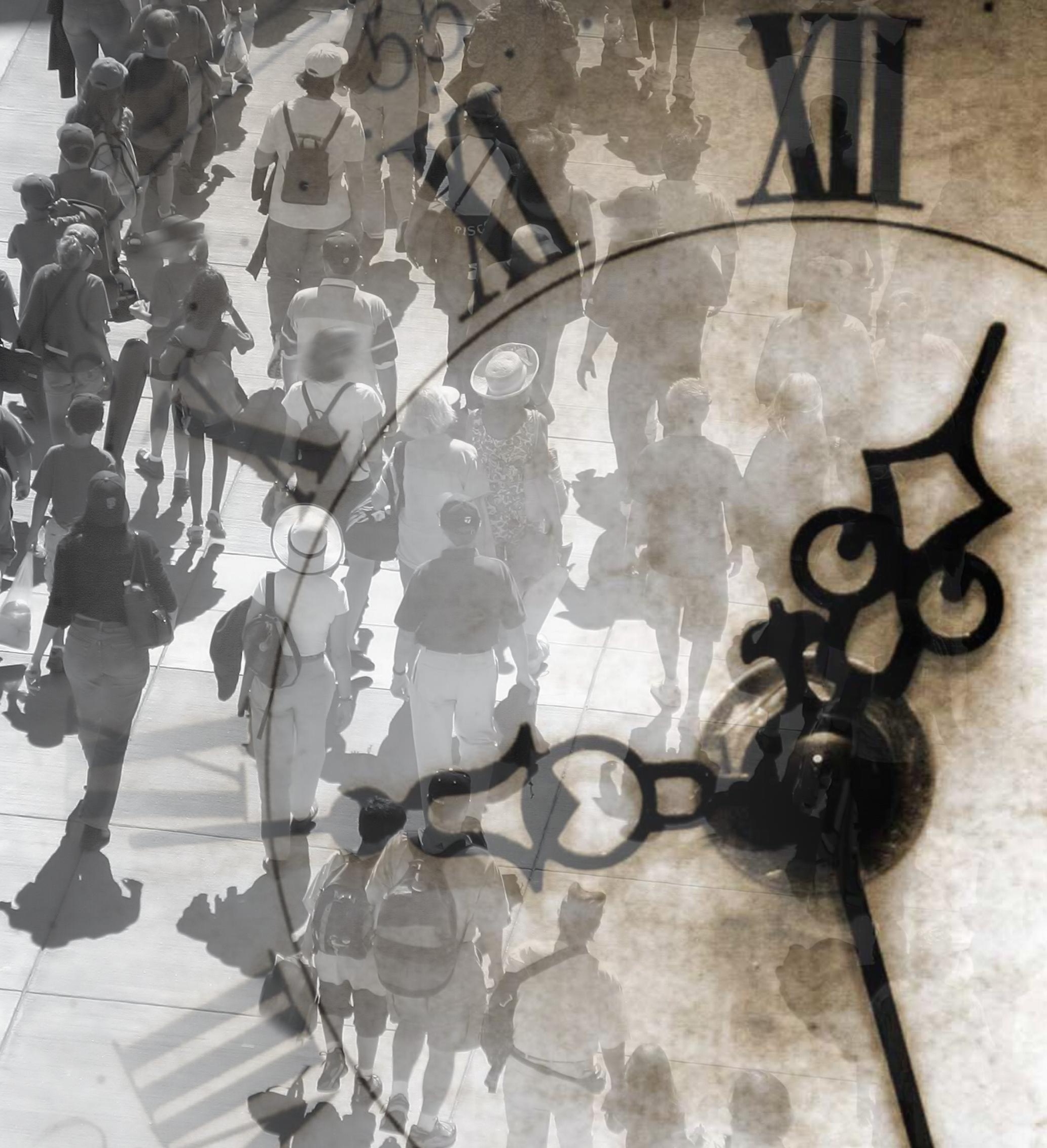




\section{Full fart framover}

I 1950-årene fattet Nordisk råd en rekke vedtak som gjorde livet lettere for borgerne i de nordiske landene. Den nordiske passunionen som rådet vedtok, gjorde det lettere for nordboerne å reise, og ble et tidlig forbilde for Schengen-samarbeidet.
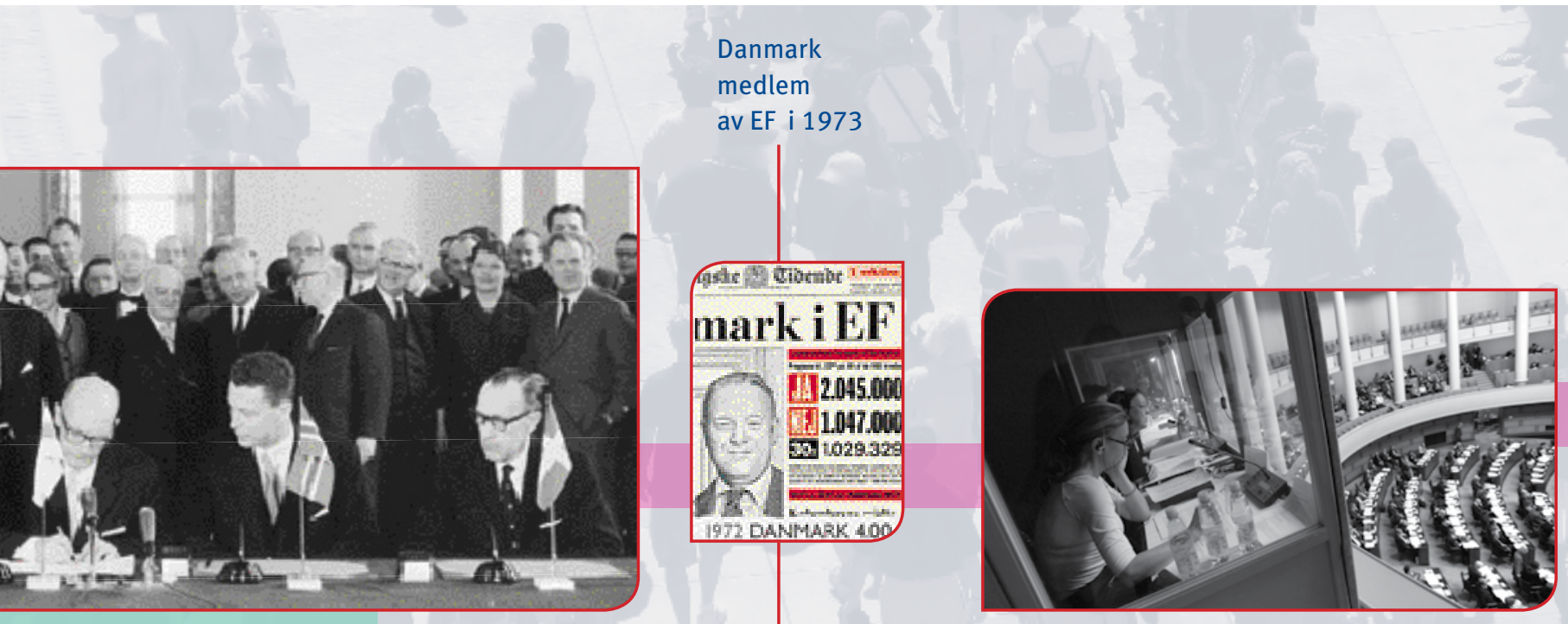

$66 \cdot 1967 \cdot 1968 \cdot 1969 \cdot 1970 \cdot 1971 \cdot 1972 \cdot 1973 \cdot 1974 \cdot 1975 \cdot 1976 \cdot 1977 \cdot 1978 \cdot 1979 \cdot 1980 \cdot 1981$

Færøyene og

Åland medlemmer i 1970
Etableringen av

en samlet

kulturavtale i 1971

Nordisk

ministerråd så

dagens lys i 1971

\section{Helsingforsavtalen}

Samtidig med at det nordiske samarbeidet ble sterkere, orienterte de nordiske landene seg også mot resten av Europa. Medlemskapene i EFTA og medlemssøknadene til EF satte fart i prosessen med å utvikle en traktat om det nordiske samarbeidet.

Helsingforsavtalen, en slags grunnlov for Norden, ble vedtatt $i$ Helsingfors 1962. I den ble det blant annet slått fast at Nordisk råd skulle ha mulighet for å uttale seg i spørsmål av prinsipiell betydning for det nordiske samarbeidet. 


\section{Stadig bredere samarbeid}

Det skulle gå noen år før Åland, Færøyene og Grønland ble medlemmer av Nordisk råd. I 1970 ble det vedtatt at Færøyene og Åland kunne delta som medlemmer av henholdsvis den danske og finske delegasjonen. De grønlandske representantene fikk plass $i$ den danske delegasjonen til Nordisk råd i 1984.
Etter at Ålandsdokumentet ble vedtatt av samarbeidsministrene i Mariehamn på Åland i 2007, har Færøyene, Grønland og Åland fått mer å si i det nordiske samarbeidet.

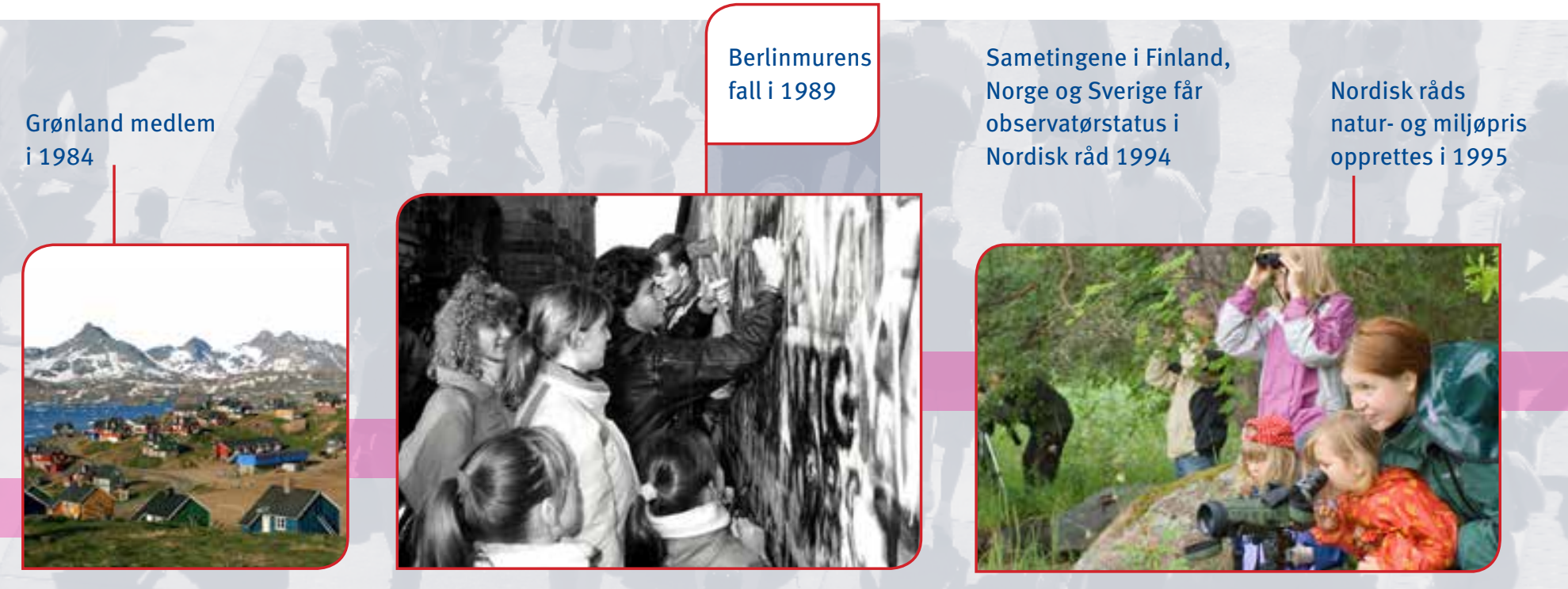

$1982 \cdot 1983 \cdot 1984 \cdot 1985 \cdot 1986 \cdot 1987 \cdot 1988 \cdot 1989 \cdot 1990 \cdot 1991 \cdot 1992 \cdot 1993 \cdot 1994 \cdot 1995 \cdot 1996 \cdot 19$

Handlingsplanen for økonomisk utvikling og full sysselsetting i 1985
Den baltiske forsamling grunnlegges med Nordisk råd som forbilde i 1991
Norge og Island medlemmer av EØS i 1994
Sverige og Finland medlemmer av EU i 1995

\section{Kulturavtalen}

Ønsket om et hurtigere, smidigere og mindre byråkratisk samarbeid på kulturområdet førte i 1971 til etableringen av en samlet kulturavtale. Målet var å øke effekten av den samlede innsatsen av landenes investering i undervisning, forskning og annen kulturell virksomhet.

\section{Nordisk råds priser}

Nordisk råd deler hvert år ut en litteraturpris, en musikkpris, en filmpris og en natur- og miljøpris.

Formålet med Nordisk råds priser er å øke interessen for de nordiske landenes litteratur, språk, musikk og film. Samtlige priser er på 350000 danske kroner. 


\section{Det europeiske samarbeidet}

I 1973 ble Danmark medlem av det mange fryktet ville gi Nordisk råd dødsstøtet, nemlig EF. Men i stedet for å smuldre vekk fikk det nordiske samarbeidet nytt liv gjennom et mer forpliktende regjeringssamarbeid $i$ Nordisk ministerråd, som så dagens lys i 1971. Norge og Island ble med i EØS 1994, noe som gjør at de følger de samme reglene for fri bevegelighet innenfor det europeiske indre markedet som de andre nordiske landene følger innenfor rammen av EU.

\section{Berlinmurens fall gir nye muligheter}

Berlinmurens fall i 1989 fikk stor betydning for utvidelsen og styrkingen av det nordiske samarbeidet med de baltiske landene og Nordvest-Russland.
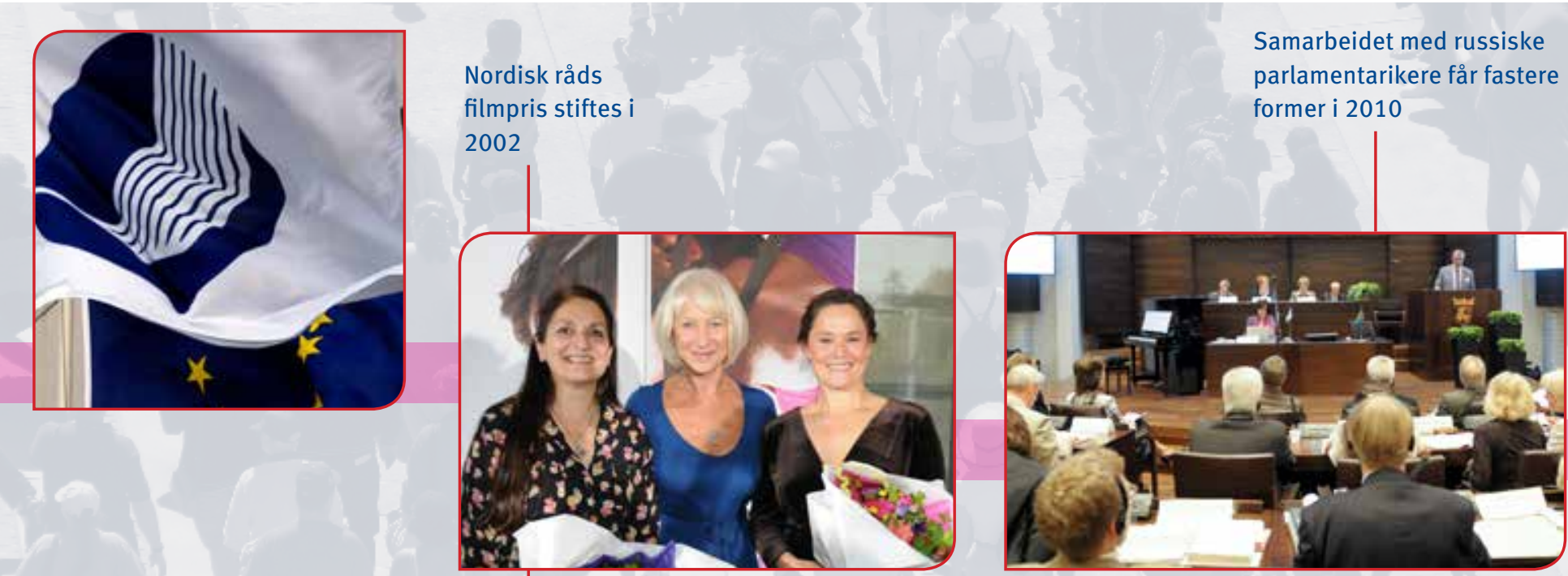

Samarbeidet med russiske parlamentarikere får fastere former i 2010

filmpris stiftes i

2002

$97 \cdot 1998 \cdot 1999 \cdot 2000 \cdot 200$

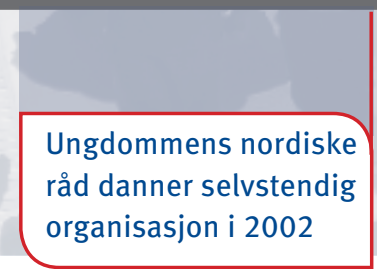

Ålandsdokumentet opprettes

5. september 2007

Parlamentarikerne i Nordisk råd har også jevnlig kontakt med andre interparlamentariske organisasjoner i Europa. Det internasjonale samarbeidet og nettverket utvikler seg hele tiden. Samarbeidet i Den parlamentariske østersjøkonferansen BSPC har som mål å styrke Østersjø-regionen som helhet.

| 2007 opprettet Nordisk råd også kontakt med både opposisjonen og parlamentssiden i Hviterussland, blant annet gjennom rundbordssamtaler. 


\section{Hvilke spørsmål arbeider Nordisk råd med?}

\begin{abstract}
Arbeidet i Nordisk råd kan forklares ganske enkelt. Det skyldes at parlamentarikerne i Nordisk råd først og fremst er drevet av ett ønske: $\emptyset n$ sket om at Norden skal være et godt sted å leve. Det er det primære målet for alle ideene og forslagene som oppstår i Rådet.
\end{abstract}

Men det er innlysende at veien til å gjøre Norden til et godt, eller bare et bedre, sted å leve ikke er snorrett. Det finnes mange utfordringer, mange interesserer, og derfor er det alltid mange forskjellige hensyn som må tas. Nordisk råd er i utgangspunktet tettere på borgerne enn Nordisk ministerråd, som er et samarbeid på regjeringsnivå - i Nordisk råd kan parlamentarikerne, i større grad enn regjeringene, samarbeide på tvers av nasjonale skiller og dermed lettere arbeide for merkesaker ut fra sin politiske overbevisning.

Blant de mest fundamentale utfordringene for Nordisk råd er spørsmål som for eksempel vedli- kehold og videreutvikling av den nordiske velferdsmodellen. I det 20. århundret var ideen om de nordiske velferdssamfunnene stort sett på konstant frammarsj. Men i dag har modellen kommet mer under økonomisk press.

\section{De kulturelle spørsmålene er} også sentrale for arbeidet $i$ rådet. Det skyldes at vi ligner på hverandre. Språkene og mentaliteten, verdiene og det generelle kulturfellesskapet vårt er overordnet sett $\mathrm{i}$ høyere grad en samlende enn en atskillende faktor. Derfor er spørsmål om nordisk kultur alltid avgjørende viktige for Nordisk råd.

\section{Av andre vesentlige spørsmål er} det verd å nevne mobiliteten for nordiske statsborgere innenfor Nordens grenser - at vi fritt kan reise fra et land til et annet er ikke en gitt rett, men et resultat av politiske beslutninger.

Hvis vi også ser ut over Nordens grenser, er det interessant å huske på at selv om det primære målet som nevnt er å sikre et godt liv for nordboere i vår del av verden, kan vi ikke bare arbeide for dette målet ved å tenke og handle i vår egen region. Derfor vil Nordisk råd ikke bare kjempe for et bærekraftig Norden, men også være medvirkende til å skape et grønnere Europa, arbeide for å skape en grønnere økonomi og stanse klimaendringene.

\section{Verdier som menneskerettig- heter, demokrati, likestilling og rettsstatsprinsipper danner kjernen for Nordisk råds internasjo- nale engasjement.}

Samarbeidet om en nordisk utenriksog forsvarspolitikk står også stadig høyt på agendaen. Norden er i stor grad påvirket av det som skjer i øvrige Europa og globalt. Derfor er EUpolitikk og de globale utfordringene en del av Nordisk råds dagsorden. Nordisk råd arbeider derfor målrettet for å gi Norden en sterk stemme i forbindelse med EU-spørsmål, som man for eksempel gjorde $i$ forbindelse med revideringen av EUs forbrukerdirektiv og utarbeidingen av EUs østersjøstrategi samt EUs fiskeripolitikk.

Kort sagt er den nordiske kontakten med omverdenen sentral for rådet. Bare ved å påvirke omverdenen kan Nordisk råd få innflytelse på internasjonal politikk og dermed også skape de best mulige resultater for innbyggerne i de nordiske landene. 


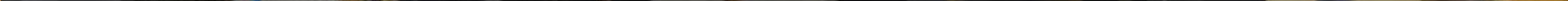




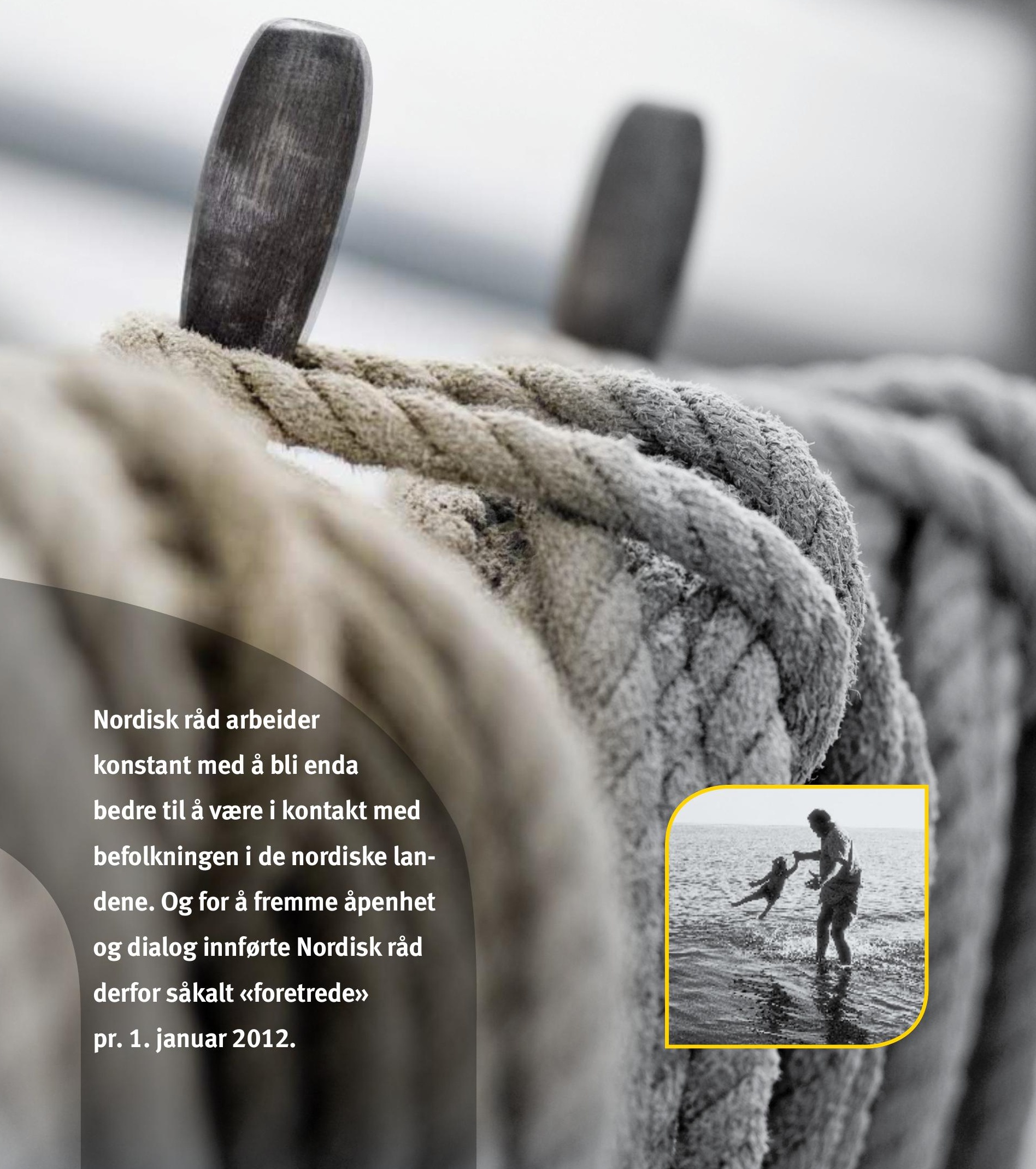




\section{Nærmere folket}

Nordisk råd arbeider konstant med å bli enda bedre til å være i kontakt med befolkningen i de nordiske landene. $0 \mathrm{~g}$ for å fremme åpenhet og dialog innførte Nordisk råd derfor såkalt «foretrede» pr. 1. januar 2012. Det betyr at enhver nordisk borger kan be om et møte med et utvalg i Nordisk råd for å legge fram sine synspunkter på rådets politikk. Det er et konkret tiltak som i enda høyere grad enn før skal gjøre Nordisk råd til ditt og mitt råd - vårt råd.

\section{Presidiet og utvalgene i Nordisk råd}

Medlemmene av Nordisk råd er fordelt i Presidiet og de fem utvalgene.

\section{Presidiet}

Presidiet er Nordisk råds politiske ledelse. Mellom sesjonene er Presidiet rådets øverste besluttende organ. Presidiet har ansvar for de overordnede politiske spørsmålene, planlegging og budsjetter og det utenriks- og sikkerhetspolitiske parlamentariske samarbeidet. Nordisk råds president og visepresident er medlemmer av Presidiet.
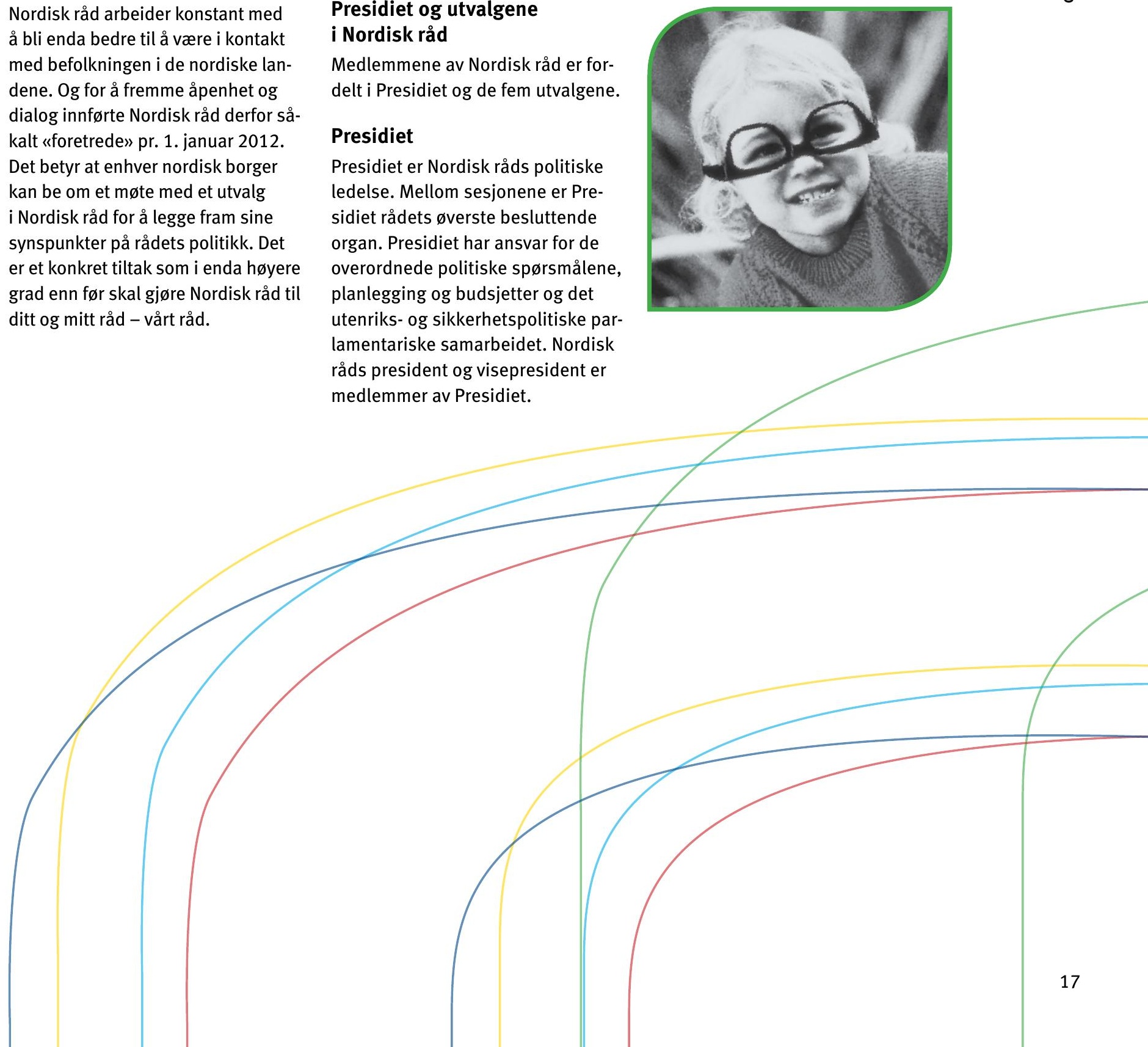


\section{Kultur- og utdanningsutvalget}

Kultur:

- Ny teknologi og medieplattformer

- Språksamarbeid

- Nyskaping innenfor kulturpolitikken, herunder forskning og analyse

\section{Utdanningsområdet:}

- Frafallsproblematikker

- Ungdomsarbeidsledighet

- Livslang læring

- Innovasjon i utdanningene

\section{Medborger- og forbrukerutvalget}

- Demokrati

- Menneskerettigheter

- Medborgerrettigheter

- Likestilling

- Forbrukerspørsmål

- Matsikkerhet

- Kriminalitetsbekjempelse, herunder internasjonal kriminalitet og terrorisme

- Justispolitiske saker

- Innvandring og flyktninger

- Samarbeid mot rasisme

- Urfolks rettigheter
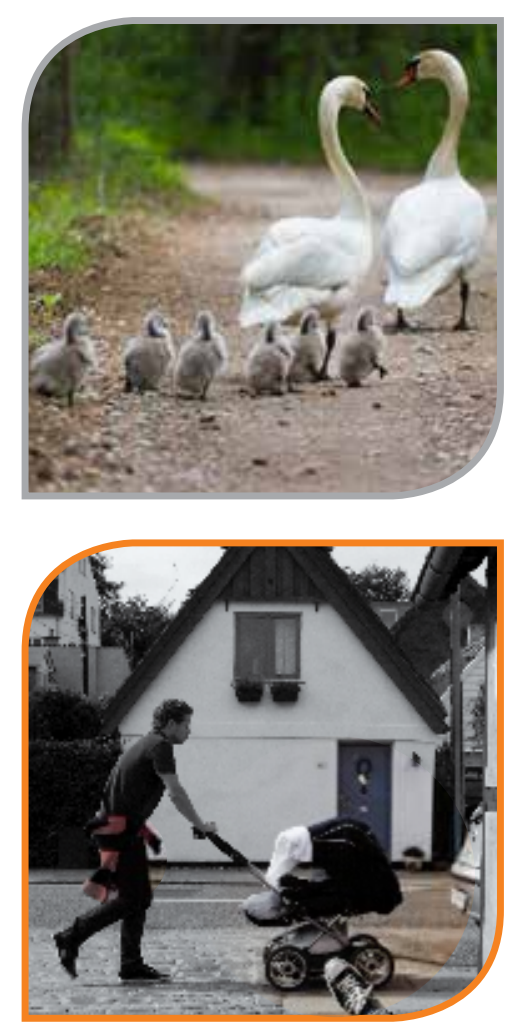

\section{Velferdsutvalget}

- Velferds- og trygghetsordninger

- Sosial- og helsespørsmål

- Funksjonshemminger

- Bygg og bolig

- Familie

- Barn og ungdom

- Narkotika, alkohol og andre misbruksformer. 


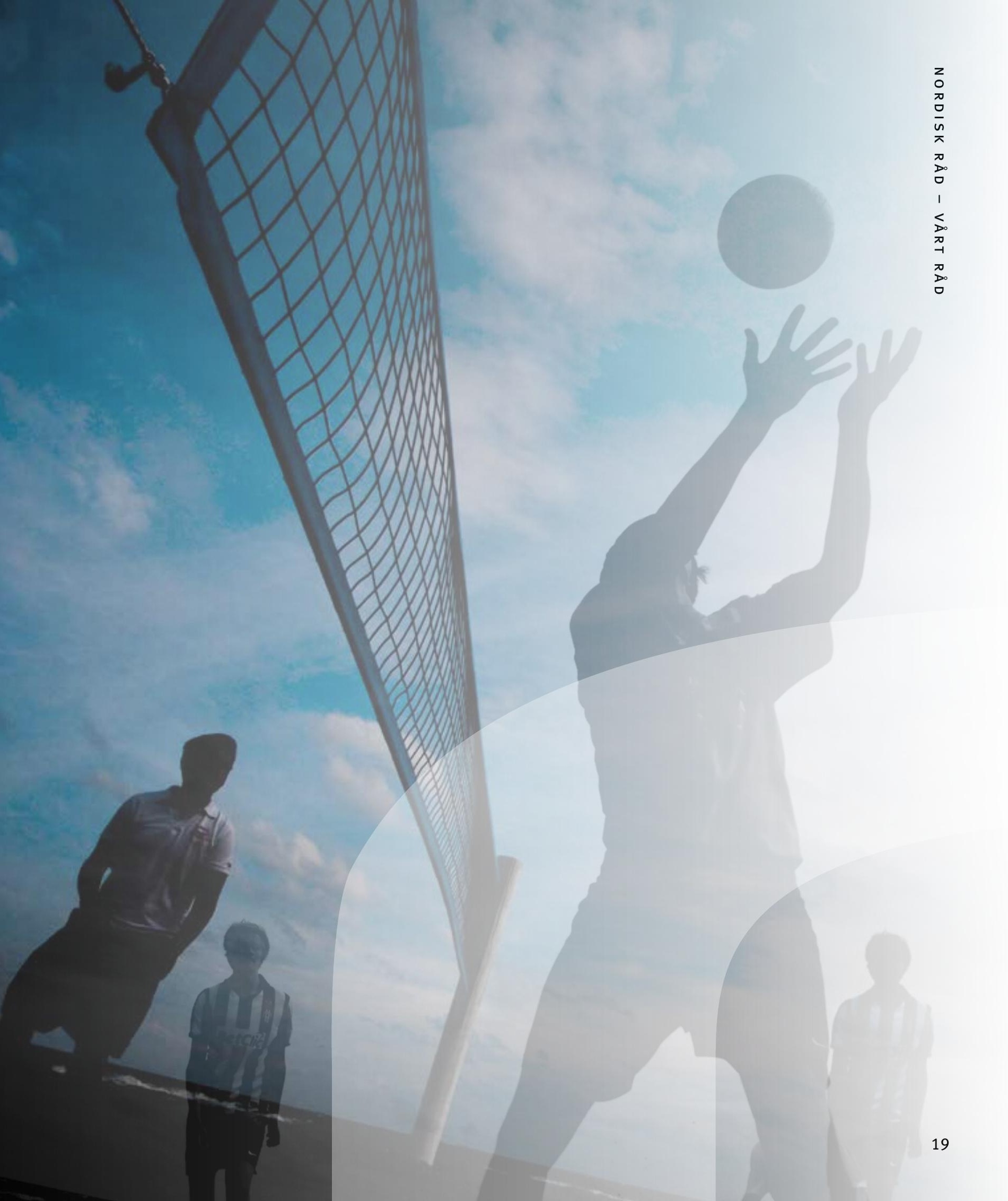




\section{Kontrollkomiteen}

Kontrollkomiteen utøver den parlamentariske kontrollen over virksomhet som finansieres med felles nordiske midler.

\section{Valgkomiteen}

Valgkomiteen forbereder valg som besluttes av plenarforsamlingen.

\section{Partigruppene i Nordisk råd}

Siden 1973 har Nordisk råds valgte medlemmer kunnet danne nordiske partigrupper. En nordisk partigruppe må omfatte minst fire medlemmer og ha representanter fra minst to land.

Ettersom en slik partigruppe må ha minst fire medlemmer fra minst to land, innebærer det at det finnes en del medlemmer som ikke tilhører noen registrert nordisk partigruppe. Nordisk råds politiske ledelse, Presidiet, fastsetter reglene for hvordan registrering av partigrupper skal gjøres.

\section{Nordisk råd har fem partigrupper:}

- Den sosialdemokratiske gruppen

- Midtengruppen

- Den konservative gruppen

- Den venstresosialistiske grønne gruppen

- Nordisk frihet 


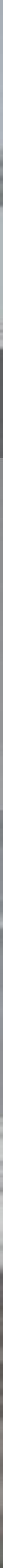




\section{Nordisk råd}

- Nordisk råd er det offisielle nordiske samarbeidets parlamentariske organ, som ble opprettet i 1952.

- Rådet er en av de tre hovedpilarene i det nordiske samarbeidet. De andre to er det folkelige samarbeidet og regjeringssamarbeidet.

- Nordisk råd gir råd og tar initiativ overfor de nordiske landenes regjeringer og Nordisk ministerråd.

- 87 medlemmer fra Danmark, Finland, Island, Norge, Sverige, Færøyene, Grønland og Åland. Danmark, Finland, Norge og Sverige har 20 medlemmer hver. Av de danske medlemmene kommer to fra Færøyene og to fra Grønland, mens to av Finlands medlemmer kommer fra Åland. Island har syv medlemmer i Nordisk råd.

- Medlemmene utnevnes av de nasjonale parlamentene etter forslag fra partigruppene.

- Det løpende politiske arbeidet finner sted i Presidiet og i de fem fagutvalgene.

- Parlamentarikerne kan påvirke det nordiske samarbeidet blant annet gjennom medlems- og utvalgsforslag, rekommandasjoner, skriftlige fremstillinger, uttalelser og skriftlige og muntlige spørsmål til de nordiske regjeringene og Nordisk ministerråd. Praksisen med spørsmål er unikt $i$ hele verden.

- Nordisk råd møtes ved to årlige sesjoner og fem årlige utvalgsmøter.

- Presidentskapet alternerer mellom medlemslandene, og varer et år av gangen.

\section{Nordisk råds \\ sesjon}

- Under Nordisk råds sesjon diskuterer Nordisk råds medlemmer politikk med regjeringsmedlemmer fra de fem nordiske landene, Færøyene, Grønland og Åland. Dette er en unik form for internasjonalt samarbeid.

- Under sesjonen avgjør parlamentarikerne hvilke forslag som skal sendes videre til de nordiske regjeringene. Dette skjer både på temasesjonen i mars og på høstsesjonen.

- Parlamentarikerne i Rådet kan stille spørsmål direkte til de nordiske ministrene under sesjonen.

- Høstsesjonen avholdes i det landet som har presidentskapet.

- Under sesjonen velges det også president, visepresident og medlemmer til Presidiet og utvalgene for året som kommer. 


\section{nordon}

Nordisk råd

Ved Stranden 18

DK-1061 København K

www.norden.org

Veien til å oppleve at Nordisk råd er vårt eget råd, går gjennom forståelse. Og den kommer fra kunnskap. Om Nordisk råds historie, om Nordisk råds sammensetning og ikke minst om hva Nordisk råd arbeider for hver eneste dag i alle de nordiske landene, men også ute i verden. For Nordisk råd vil og kan gjøre en forskjell for befolkningene i Norden, og forhåpentlig også for andre land og befolkningene der.

I denne brosjyren får du vite mer om hva Nordisk råd dreier seg om. Du vil oppdage at Nordisk råds arbeid også påvirker ditt liv. Kanskje vil du også være med på å påvirke Nordisk råd.

ISBN 978-92-893-2375-8

http://dxdoi.org/10.6027/anp2012-734

ANP 2012:734 